\title{
The 2015 Table Mountain ICe Patch Project: Grand Teton National Park, Teton County, WY
}

\author{
MARCia PETERSON \\ OFFICE OF THE WYOMING STATE ARCHAEOLOGIST $\uparrow$ LARAMIE, WY
}

\section{$\downarrow \quad$ AbSTRACT}

Ice patches are permanent snow and ice fields that survive through the summer months but are not massive enough to become glaciers. Prehistorically, people used ice patches for hunting, and organic hunting-related artifacts have been recovered from them. As a result of global warming, the ice patches are melting and exposing artifacts and other material that were preserved under the ice for millennia. Once exposed, the organic artifacts deteriorate. Recovery of these artifacts before they are lost is critical to understanding the paleoecology of and the prehistoric people who used the Teton high elevations (Lee 2009, 2015). In 2015, I surveyed ice patches on Table Mountain pursuant to Section 110 of the National Historic Preservation Act. The work was conducted under OWSA permits 15-GRTE-01 and GRTE-2015SCI-0040 and was partially funded by the UW-NPS Research Station. One historic archaeological site (48TE1983) was documented and four paleobiological specimens were collected.

\section{$\downarrow \quad$ ENVIRONMENTAL SETTING}

Table Mountain is located on the western boundary of Grand Teton National Park (the park) in the Teton Range. It consists of remnant limestone, shale, and sandstone that was originally deposited in large shallow seas during the Paleozoic Period before the Teton Range rose. Most of the sedimentary rocks have eroded exposing the granite, gneiss, and schist beneath, but Table Mountain remains (Craighead 2006, Love et al. 1992, Love and Reed 1968). The project area is located above tree line between 10,720 and $11,100 \mathrm{ft}$. above sea level in an alpine vegetation zone (Knight et al. 2014). The Table Mountain ice patches consist of three smaller noncontiguous patches on the eastern and northern sides of the mountain. Dr. Craig Lee (2014) designated the two larger of these $\mathrm{AB} 11 \_\mathrm{A}$ and AB12_C (Figure 1). The "AB" stands for the Alaska Basin, and the rankings " $\mathrm{A}$ " and "C" indicate their generally high potential for archaeological or paleobiological material (Lee 2014).



Figure 1. Table Mountain ice patches looking west (Photo by $\mathrm{M}$. Peterson, $8 / 25 / 2015$ ).

\section{$\downarrow \quad$ BACKGROUND RESEARCH}

A review of regional ice patch literature revealed that chipped stone artifacts (Lee 2012), modified wooden objects (Sgouros and Stirn 2015, Lee 2014), arrow/dart shaft fragments (Reckin 2013, Lee 2010, 2012), bows (Kelly, personal communication 2015), leather/bark artifacts (Reckin 2013, Lee 2012), basketry and cordage (Lee, personal communication 2016, Reckin 2013), digging or walking sticks (Lee 2012), burned wood (Reckin 2013, Lee 2012), trees (Lee 2012), and culturally modified and unmodified sheep, bison, elk, and deer bone (Reckin 2013, Lee 2012) have been recovered from ice patches in the Middle Rocky Mountains. 
Further, on July 27, 1872, famous pioneer photographer William Henry Jackson along with Charles Campbell, Philo Beveridge, Alexander Sibley, and possibly John Colter took off on horseback with two pack mules to explore Teton Canyon and summit Table Mountain (Blair 2005, Daugherty 1999). Jackson's goal was to take the first photographs of the Grand Teton from its western side (Jackson 1994). His photography equipment consisted of a canvas dark tent, $11 \times 14$ inch and $8 \times 10$ inch cameras, developing plates, chemicals for developing, and wooden containers for washing the plates (Figure 2, Upper). With his equipment loaded on the mules, they crossed the ice patch on the eastern side of Table Mountain to reach the perfect spot for the photos. Jackson spent one day photographing the Tetons. He saw a bighorn sheep watching him from Table Mountain (Figure 2, Lower), and he also noted many sheep, bears, elk, deer, and moose while around Table Mountain (Jackson 1994, Blair 2005).


Figure 2. Sketch of Jackson's dark tent on Table Mountain (Upper) (Jackson 1994:206) and Jackson ca 1929 representation of the bighorn sheep (Lower) (Blair 2005:82).

\section{$\uparrow \quad$ METHODS}

This project involved the pedestrian inventory of the ice patches around Table Mountain on August 9 and 25,2015. All margins of the ice patches were examined, including the fore-fields, runoff channels, and surfaces of the lower-sloped areas. Overview photos were taken from far enough away to allow the extent of the ice to be compared annually (Lee 2015). One historic wallet, two bison bones, and three sticks were collected. Archival-quality Coroplast fluted plastic board and rolled cotton bandages were used to stabilize the collected bones and sticks and transport them from the field (Lee 2015) (Figure 3). The wallet was sealed in an archival quality plastic bag and kept in a cooler until taken to the University of Wyoming Archaeological Repository for conservation (Figure 4).

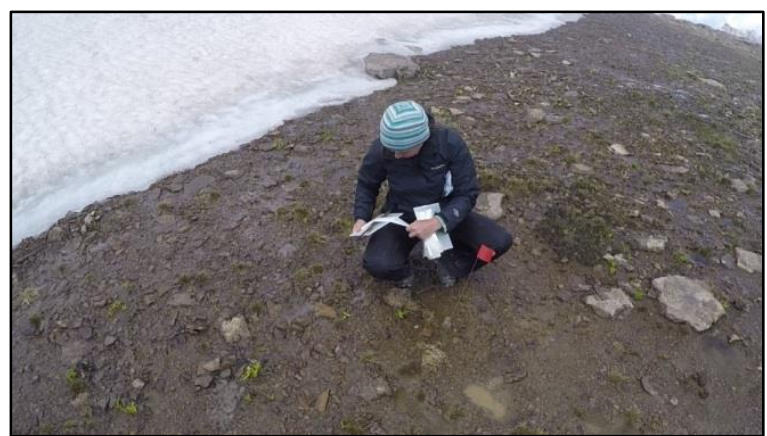

Figure 3. Collecting/transporting organic artifacts (Photo by C. Castle, 8/9/2015).

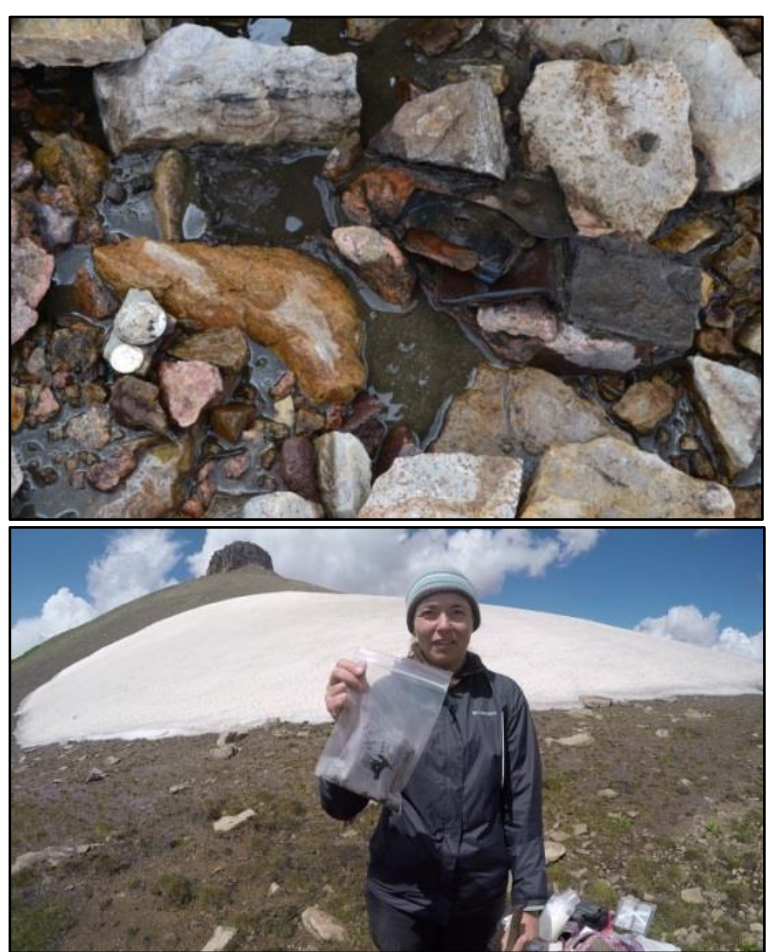

Figure 4. Close-up of the wallet at the time of discovery looking south (Upper) and packaged for transport looking west (Lower) (Photos by M. Peterson and C. Castle, 8/9/2015). 
The University of Wyoming Archaeological Repository contacted Spicer Art Conservation, LLC (Spicer) to process the wallet and save it and as many of its contents as possible. Spicer examined the wallet on August 18, 2015 (Figure 5, Upper). She performed conservation treatment from August 20 to November 25, 2015. Following conservation, she rehoused the contents of the wallet in a custom-made acid free box and returned them to OWSA (Conservation Treatment Report 2015) (Figure 5, Lower).
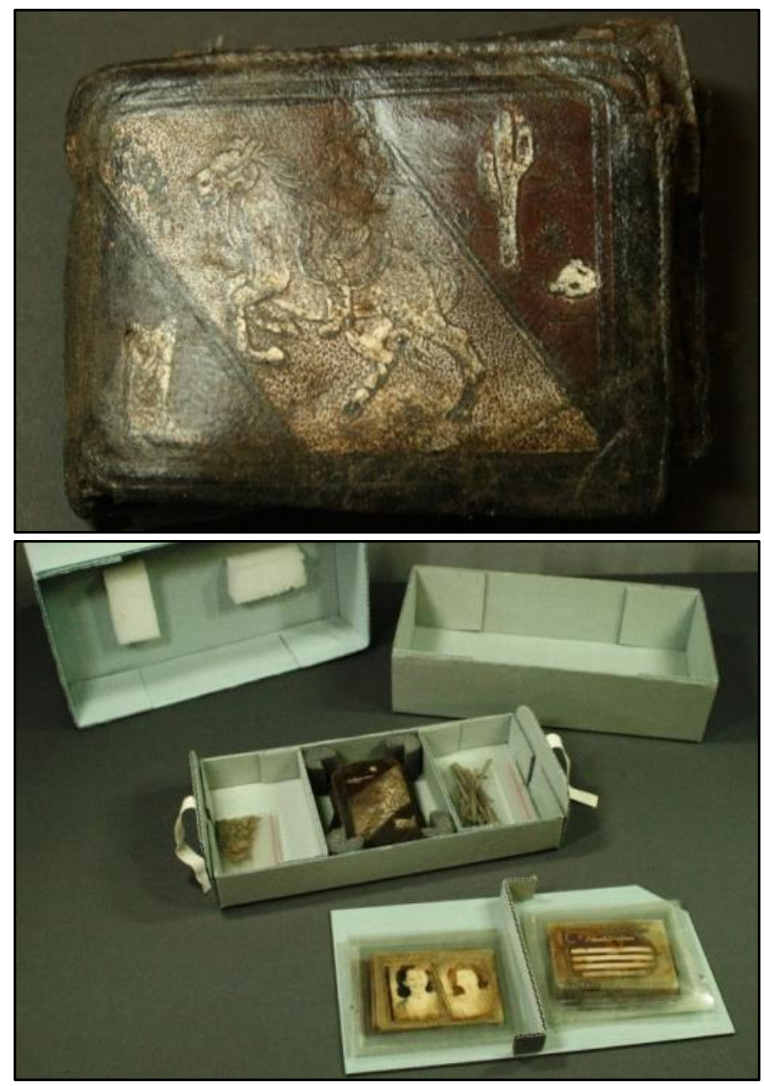

Figure 5. The wallet prior to and after treatment (Photos by Spicer, 8/20/2015 and 11/16/2015).

I processed a token found in the wallet by soaking it in increasingly acidic liquids until enough corrosion was removed. It was first soaked in mildly acidic olive oil for about two weeks and periodically scrubbed using a soft bristle brush. The olive oil did not remove enough corrosion, so it was soaked in Diet Pepsi ( pH 3) for about one week and periodically scrubbed using a soft bristle brush. The Diet Pepsi removed some corrosion but not enough for identification, so it was soaked in distilled white vinegar ( $\sim \mathrm{pH} 2.4)$ for approximately one week and periodically scrubbed using a soft bristle brush. The vinegar removed enough corrosion from the token for identification.
Dr. Kathryn Puseman of Paleoscapes Archaeobotanical Services Team (PAST), LLC identified the wood specimens. She measured each stick then removed a piece of each for identification. The fragments were broken to expose fresh, cross, tangential, and radial sections and examined under a Bausch and Lomb Stereozoom microscope at a magnification of 70x and under a Nikon Optiphot 66 microscope at magnifications of 100-600x. She recorded images with an AmScope 10MP microscope digital camera and identified the wood with standard wood identification manuals, internet web sites, and a modern comparative collection (Puseman 2016).

Beta Analytic and the University of Arizona AMS Laboratory completed accelerator mass spectrometry dates on the collected wood and bone samples, respectively, using standard AMS procedures for wood and bone (Beta Analytic Inc. 2016, University of Arizona AMS Laboratory 2016).

\section{$\downarrow \quad$ RESULTS}

One historic site, 48TE1983, was located. In addition, two unmodified sticks and two bison bones were collected for identification and/or radiocarbon dating.

\section{Site 48TE1983}

Site 48TE1983 is a historic site located on the northern and eastern sides of Table Mountain (Figure 6 ). The site has been extremely impacted by modern recreation, dense trash, collection/vandalism, and erosion. It consists mostly of 1940 s to 1960 s historic debris associated with the recreational use of Table Mountain. Artifacts include a historic wallet from the mid to late 1940s (collected), one carved Boy Scout troop stick in three segments (collected), other carved walking sticks and worked sticks (two collected), food cans, one lard pail, 1960s Shasta soda cans, other tin cans, one clear glass 1958 Canada Dry bottle, condensed milk cans, puncture/church key opened beverage cans, short tin cans, clear glass fragments, one coffee can, meat tins, one Hershey's tin, one clear glass 1953 Big Chief beverage bottle, unidentifiable tin can and metal fragments, milled lumber, and one moccasin of unknown antiquity. Dense modern trash is intermixed with the historic debris. 


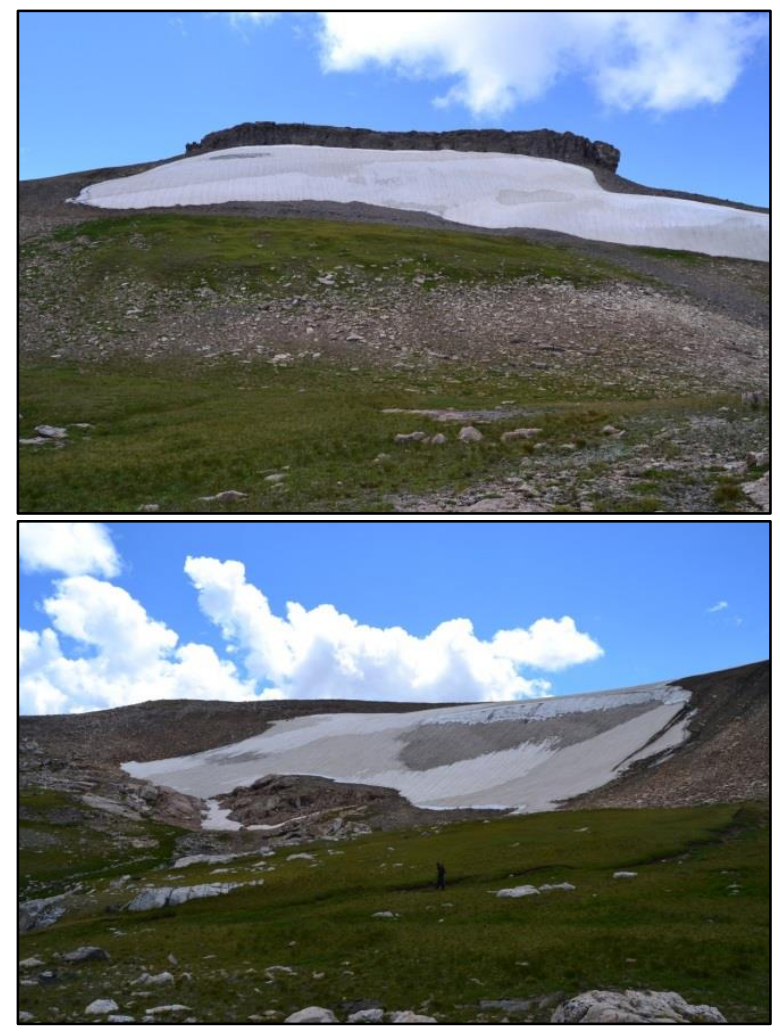

Figure 6. Site 48TE1983 looking south (Upper) and southeast (Lower) (Photos by M. Peterson, 8/9/2015).

The wallet's cotton stitching had completely deteriorated, but the leather was in good shape. The cover was tooled and painted leather with a horse and rider in the center, a boot on one side, and a cactus on the other (Figure 5, Upper). Also, portions of an address book, photographs, and documents were partially preserved and four coins and one metal token were recovered. The conserved paper contents of the wallet indicate it was owned by Gordon Stokes, a young man from Rigby, Idaho. His name was visible on a certificate naming him a Star Scout on March 21, 1947 and on a piece of a letter from Dr. Aldon Tall dated January 9, 1946 (Figure 7). The date of 1947 is the latest date identified and is likely the year that it was lost. He was born on February 11, 1933, in Ogden, Utah, and as of April 1940, he lived in Rigby, Idaho with one sister two years younger and one brother five years younger. He may still have lived in Rigby when he lost his wallet given that he was in Rigby Boy Scout Troop 29 in 1947 and had some barely legible addresses in the address book that were in Rigby. He would have been around 14 years old when he lost his wallet, which is consistent with its contents and style. He died on August 20, 2012, in Provo, Utah and is buried in a cemetery there. He served in the US Navy and taught in the Computer Science department at BYU for 30 years. He was married and had nine children. The wallet contained photographs, many of which are well-preserved (http://interactive.ancestry.com; http://www.findagrave.com).

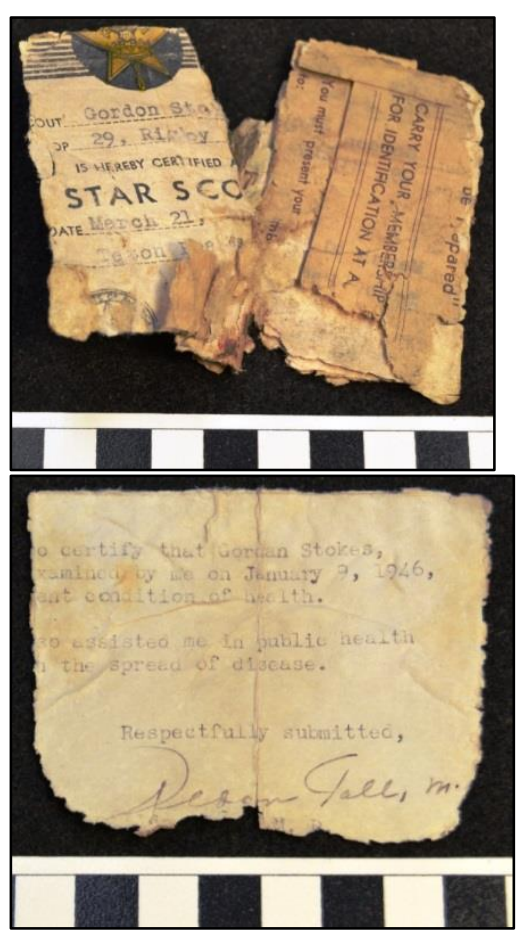

Figure 7. Pieces of the Star Scout Certificate (Upper) and letter from Dr. Tall (Lower) (Photos by M. Peterson, 1/19/2017).

The coins were the best preserved contents in the wallet. They include one 1924 Peace silver dollar, two quarters (1943 and 1944), and one 1944 wheat penny (Figure 8, Upper). In addition, one metal token was recovered. It is a brass pocket guardian angel token about the size of a quarter (Figure 8, Lower). Charities have given out these tokens since the mid1940 s in exchange for donations (http://www.stampboards.com/viewtopic.php?f=27\&t =26845; http://www.crs.org/?gclid=CJj0jtHG29E

CFY-1wAodKRgIbA). They are religious good luck coins that are carried for fortune, and the practice dates back to as early as 1792 (https://www.reference.com/hobbiesgames/guardian-angel-coins-1d9f93b9315cf6da).

The Treasure Mountain Boy Scout Camp is located in Teton Canyon near the Table Mountain trailhead. It started in 1936 and continues today (https://www.facebook.com/TreasureMountainBSA/ about/). Since the young man was a Boy Scout in 1947, it is likely he was a Treasure Mountain camper in the summer of 1947 and lost his wallet on the Table Mountain hike. 


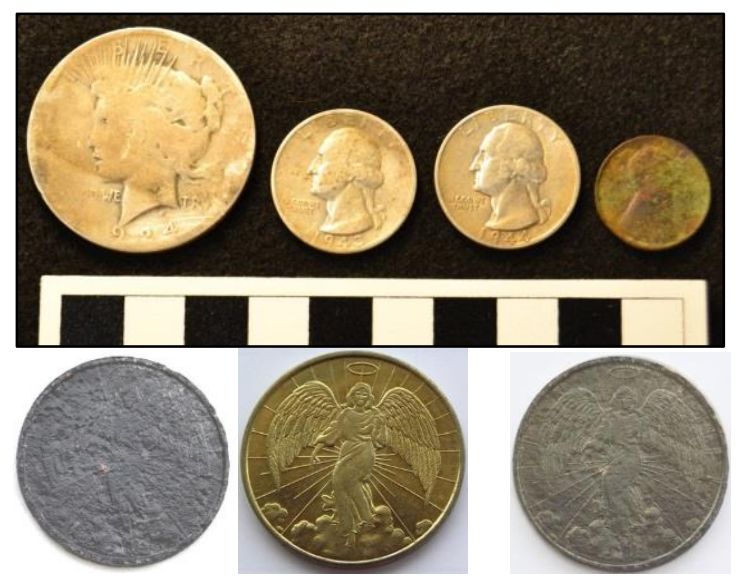

Figure 8. The Peace Silver Dollar, 1943 and 1944 Quarters, and 1944 Wheat Penny (Upper) and the Guardian Angel Token: Collected token (Lower Left); pristine token (Lower Center; http://www.terapeak.com/worthguardian-pocketangel-1-token-coin-goldtone-wings-clouds-goldtone-rimvintage/371554486545/); and pristine token superimposed on the collected token (Lower Right) (Photos by $\mathrm{M}$. Peterson, 1/18-19/2017).

Further, three worked sticks were collected from the melting ice patch. One is a carved Boy Scout walking stick in three segments. The segments refit to form a 151-cm long walking stick with an average diameter of $2 \mathrm{~cm}$ and "TROOP 4" or "TROOP 11" carved near its midsection (Figure 9). Given that it was found near the historic wallet and the Treasure Mountain Boy Scout Camp has been operating since 1936 , it is possible that this stick is also historic $(>50$ years old).
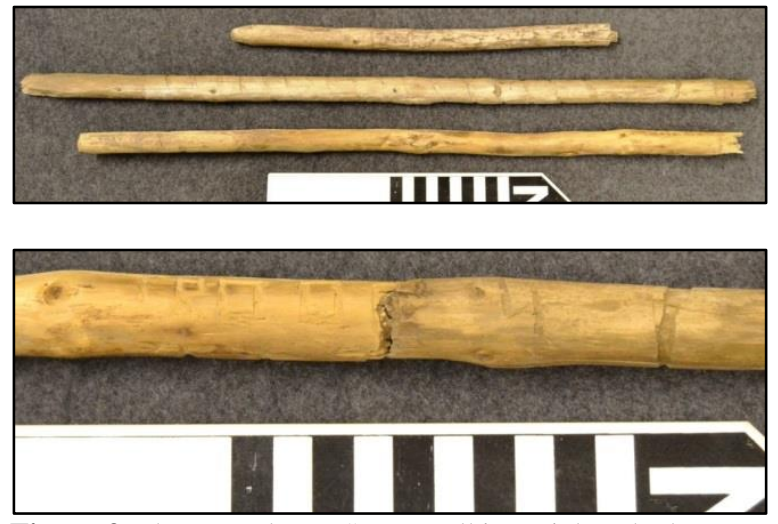

Figure 9. The carved Boy Scout walking stick. The bottom segment is the top, the middle segment is the midsection, and the top segment is the bottom (Upper photo). The bottom photo shows the refit ends where it reads "Troop 4" or "Troop 11" (Photos by M. Peterson, 1/19/2017).

The other two collected worked sticks were found melting from the ice patch near the Boy Scout walking stick. The functions of both are unknown.
One stick is carved to a blunt point on one end and measures $15.7 \mathrm{~cm}$ long with a diameter of $1.3 \mathrm{~cm}$ (Figure 10, Upper). Dr. Puseman identified the stick as Pinus sp. (pine) (Puseman 2016). Beta Analytic returned a calibrated radiocarbon date of AD 16851730, AD 1810-1925, and post AD 1950 (Beta441531). The last collected stick is $127 \mathrm{~cm}$ long with a diameter from 13 to $17 \mathrm{~mm}$. Both ends are sharpened, but the thicker end is more tapered and may have been burned. The narrower end of the stick has a notch carved in it $6 \mathrm{~cm}$ from the end (Figure 10, Lower). Dr. Puseman identified the stick as Pinus sp. (pine) (Puseman 2016). Beta Analytic returned a calibrated radiocarbon date of AD 1680-1735, AD 1755-1760, AD 1800-1935, and post AD 1950 (Beta441532).

Both sticks' dates cross the calibration curve in multiple areas, making pinpointing their actual ages difficult; but, they are likely historic. They might relate to the 1872 Hayden Expedition when Jackson was photographing the Grand Teton, or they are more sticks associated with the Boy Scouts who have frequently made this trek since 1936 , or with other historic recreational use of the area. Also, they might relate to Late Prehistoric/Protohistoric Native American use of the mountains from AD 1680-1760, or they could relate to the early fur trade.
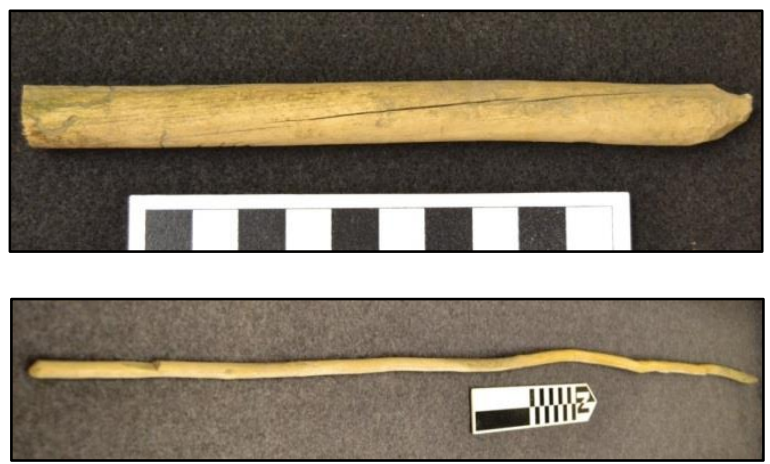

Figure 10. The worked stick showing the carved point on the right end (Upper) and the long notched stick (Lower) (Photos by M. Peterson, 1/19/2017).

\section{Paleobiological specimens}

Two unmodified sticks were collected from the ice patch ( 10,975 fasl) on August 9, 2015 (Figure 11). Dr. Puseman identified both sticks as Pseudotsuga menziesii (Douglas-fir) (Puseman 2016). Neither of these sticks has been dated. Currently, 58\% of Grand Teton National Park is non-forested, and modern tree line is around 9,500 ft. Approximately $4 \%$ of the forested land is Douglas fir woodland (Knight et al. 2014). Douglas-fir is present in Grand Teton National Park as a dominant forest species 
between around 5,500 to just over 7,000 ft., and it has only been documented up to $9,000 \mathrm{ft}$. (Knight et al. 2014). Douglas fir grows best on soil derived from sedimentary rocks, and it can grow at higher elevations in such a substrate (Knight et al. 2014, Evert 2010, Powell and Hansen 2007, Romme and Turner 1991, Despain 1990, Patten 1963). It prefers drier and warmer environments, and it can act as a good indicator of climate change (Gugger and Sugita 2010).

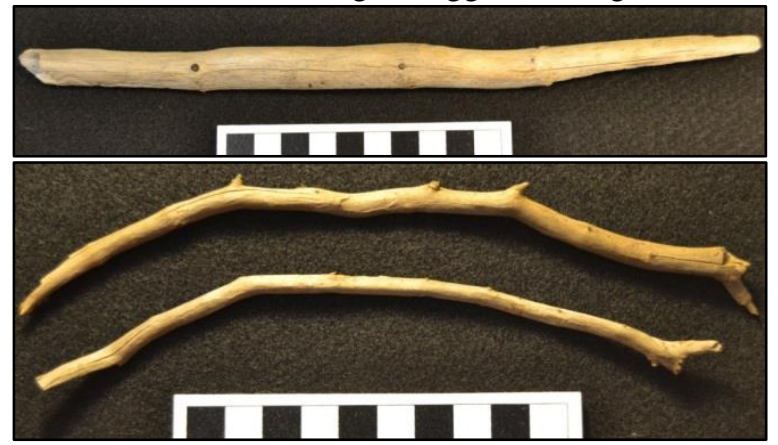

Figure 11. Collected stick 1 (Upper) and stick 2 (Lower) (Photos by M. Peterson, 1/19/2017).

Paleoclimatic studies indicate that during the early to middle Holocene ( 9,000-5,000 years ago), the park experienced a period of maximum warmth. Tree line was at a higher elevation and there was a higher ratio of Douglas fir to pine (Whitlock 1993, Whitlock and Bartlein 1993, Gugger and Sugita 2010, Romme and Turner 1991). Cool, wet conditions returned in the late Holocene, and Douglas fir numbers declined and its elevation lowered (Whitlock 1993). The Douglas fir samples I collected indicate that it may have grown up to $\sim 10,975 \mathrm{ft}$. above sea level at some time in the past. Table Mountain is comprised of remnant sedimentary rocks, which produce an optimal substrate for growing Douglas fir, and if it was warm and dry enough, maybe it grew this high. Or, given that the sticks would represent Douglas fir at almost 2,000 $\mathrm{ft}$. higher than where it has been documented in the park, the sticks may be manuports. They need to be dated to determine which scenario is most likely and to add another age for the ice patch.

Also, I collected two bison bones as paleobiological specimens to determine when bison were at this high of an elevation in the Tetons, as bison are not currently found at these elevations $(\sim 10,800 \mathrm{ft}$. above sea level) (Figure 12). I identified one bone as a bison thoracic vertebra and the other bone as a bison rib. The University of Arizona AMS Laboratory dated the vertebra to 1,021-1,218 cal. years BP and the rib to 1,027-1,183 cal. years BP (University of Arizona AMS Laboratory 2016). The dates overlap and likely represent remains from the same animal or animals that died at the same time.



Figure 12. Collected bison vertebra (Upper) and rib (Lower) (Photos by M. Peterson, 2/22/2016).

Now, less than 1,000 bison live in the park, but they are not commonly found in the Teton high country (https://www.nps.gov/). It was originally believed that mountain economies focused on artiodactyls other than bison and that bison in the mountains were limited (Cannon et al. 2015). Little is understood of the range extent of pre-contact bison in the Tetons, and the evidence we have of these bison comes from archaeological sites that have been excavated in the valleys (Cannon et al. 2015). Continued investigations in the Tetons show that bison were more prevalent in the faunal community than originally thought, and bison range extended higher into the mountains than previously documented (Cannon et al. 2015, Peterson 2017). At Table Mountain, we have documented bison bone at around $10,800 \mathrm{ft}$. that date to 1,021-1,218 cal. years BP. Bison may have targeted ice patches in the high country to escape heat and insects and because they were relatively easy to access and did not use the high country when lowland temperatures did not necessitate it or too much high country summer snow inhibited travel (Reckin 2013, see also Lee 2012, Lee et al. 2014, Ion and Kershaw 1989, Ryd 2010). Climatic studies identified three periods of glacial advance during the Holocene: the Little Ice Age ( 450-100 cal. years BP); a short period from 1,200$1,050 \mathrm{cal}$. years BP; and a longer period from 2,9002,100 cal. years BP (Reckin 2013). The Table Mountain bison bones' dates overlap with the 1,200$1,050 \mathrm{BP}$ stadial and show that at least during that stadial, bison used the high country even when conditions may not have been favorable. A larger sample of dated bison bone is needed to draw broader conclusions on bison ice patch usage. 


\section{$\downarrow \quad$ DISCUSSION}

Site 48TE1983 could provide significant information about the early historic exploration of the Tetons and recreational use of Table Mountain. It is associated with the first photographs of the Grand Teton, and artifacts associated with that expedition may be present. Also, it might be significant to the Boy Scouts of America and the historical use of Treasure Mountain Boy Scout Camp. Further, two of the sticks potentially date to the Late Prehistoric/Protohistoric periods and could provide significant information on Native American use of the high Tetons. With $\sim 900$ year old bison bone and sticks that might date to the Late Prehistoric/Protohistoric, it could be a prehistoric site, too. It could yield more animal bone that might indicate which species were exploited in the higher elevations, or it could yield perishable artifacts associated with prehistoric hunting and gathering. Ice patch artifacts could help answer questions, such as: What role ice patches played in prehistoric hunter-gatherer subsistence and settlement systems (Vanderhoek et al. 2012, Andrews et al. 2012); What the designs of and materials used in prehistoric weapons were (Andrews et al. 2012, Alix et al. 2012); How alpine people organized their technologies to take advantage of the resources available (Alix et al. 2012); When technological transitions occurred and how hunting changed over time (Hare et al. 2012, Voosen 2013); How prehistoric people adapted to the alpine environment (Andrews et al. 2012); When ice patches were used and what floral, faunal, and mineral resources were exploited (Vanderhoek et al. 2012, Callanan 2012, Dixon et al. 2005, Lee 2009, 2010, 2011, 2012).

\section{$\downarrow$ Literature Cited}

Alix, C.P., G. Hare, T.D. Andrews, and G. MacKay. 2012. A thousand years of lost hunting arrows: Wood analysis of ice patch remains in Northwestern Canada. Arctic 65 (Supp. 1):95-117.

Andrews, T.D., G. MacKay, and L. Andrew. 2012. Archaeological investigations of alpine ice patches in the Selwyn Mountains, Northwest Territories, Canada. Arctic 65 (Supp. 1):121.

Beta Analytic Inc. 2016. Report of radiocarbon dating analyses. Beta Analytic Inc. Prepared for Office of the Wyoming State Archaeologist, Laramie, WY.

Blair, B. (ed.). 2005. William Henry Jackson's 'The Pioneer Photographer'. Museum of New Mexico Press, Santa Fe, NM.
Callanan, M. 2012. Central Norwegian snow patch archaeology: Patterns past and present. Arctic 65 (Supp. 1):178-188.

Craighead, C. 2006. Geology of Grand Teton National Park: How the mountains came to be. Grand Teton Association, Moose, WY.

Daugherty, J. 1999. A place called Jackson Hole: The historic resource study of Grand Teton National Park. Grand Teton National Park, Moose, WY.

Despain, D.G. 1990. Yellowstone Vegetation: Consequences of Environment and History in a Natural Setting. Roberts Rinehart Publishers, Boulder, CO.

Dixon, E.J., W.F. Manley, and C.M. Lee. 2005. The emerging archaeology of glaciers and ice patches: Examples from Alaska's WrangellSt. Elias National Park and Preserve. American Antiquity 70(1):129-143.

Evert, E.F. 2010. Vascular Plants of the Greater Yellowstone Area: Annotated Catalog and Atlas. Erwin F. Evert, Park Ridge, IL.

Hare, P.G., C.D. Thomas, T.N. Topper, and R.M. Gotthardt. 2012. The archaeology of Yukon ice patches: New artifacts, observations, and insights. Arctic 65 (Supp. 1):118-135.

Jackson, W.H. 1994. Time Exposure. The Patrice Press, Tucson, AZ.

Knight, D.H., G.P. Jones, W.A. Reiners, and W.H. Romme. 2014. Mountains and Plains: The Ecology of Wyoming Landscapes, $2^{\text {nd }}$ Edition. Yale University Press, New Haven, CT.

Lee, C.M. 2009. Ice of the edge: Changing climate and archaeological resources. Electronic document, http://instaar.colorado.edu/ice_archaeology/, accessed February 21, 2015.

Lee, C.M. 2010. Global warming reveals wooden artifact frozen over 10000 years ago in the Rocky Mountains. Antiquity 84(325) online project http://antiquity.ac.uk/projgall/Lee325/.

Lee, C.M. 2011. Ice patch archaeology. pp. 132-143 In: D.H. MacDonald, and E.S. Hale (eds.). Yellowstone Archaeology: A Synthesis of Archaeological Papers on the Prehistory and History of Yellowstone National Park, Vol. I.

Lee, C.M. 2012. Withering snow and ice in the midlatitudes: A new archaeological and paleobiological record for the Rocky Mountain Region. Arctic 65(Supp. 1):165177. 
Lee, C.M. 2014. Melting snow and ice at the crossroads of culture and climate change, phase 1: Ranking Greater Yellowstone Area snow and ice resources with archaeological and paleobiological potential. Prepared for the Greater Yellowstone Coordinating Committee. Copies available from Dr. Craig Lee, Bozeman, MT.

Lee, C.M. 2015. Field Guide: Snow and Ice Patch Survey Techniques. Copies available from Dr. Craig Lee, Bozeman.

Love, J. D., and J.C. Reed, Jr. 1968. Creation of the Teton Landscape: The Geologic Story of Grand Teton National Park. Grand Teton National History Association, Moose, WY.

Love, J. D., J.C. Reed, Jr., and A. C. Christiansen. 1992. Geologic Map of Grand Teton National Park, Teton County, Wyoming. Miscellaneous Investigations Series Map 12031. U.S. Geological Survey.

Patten, D. T. 1963. Vegetational pattern in relation to environments in the Madison Range, Montana. Ecological Monographs 33(4):375406.

Powell, S.L., and A.J. Hansen. 2007. Conifer cover increase in the Greater Yellowstone Ecosystem: Frequency, rates, and spatial variation. Ecosystems:1-13.
Puseman, K. 2016. Identification of sticks from ice patches near Table Mountain, Grand Teton National Park, Wyoming. Paleoscapes Archaeobotanical Services Team, LLC. Prepared for Office of the Wyoming State Archaeologist, Laramie, WY.

Reckin, R. 2013. Ice patch archaeology in global perspective: Archaeological discoveries from alpine ice patches worldwide and their relationship with paleoclimates. J. World Prehist. 26:323-385.

Romme, W.H., and M.G. Turner. 1991. Implications of global climate change for biogeographic patterns in the Greater Yellowstone Ecosystem. Conservation Biology 5(3):373386.

Sgouros, R.A., and M.A. Stirn. 2015. An ice patch artifact and paleobiological specimen from the Teton Mountains, Wyoming, USA. Journal of Glacial Archaeology 2(1):3-24.

University of Arizona AMS Laboratory. 2016. Radiocarbon analytical report. University of Arizona AMS Laboratory. Prepared for Office of the Wyoming State Archaeologist, Laramie, WY.

Vanderhoek, R., E.J. Dixon, N.L. Jarman, and R.M. Tedor. 2012. Ice patch archaeology in Alaska: 2000-10. Arctic 65 (Supp. 1):153164.

Voosen, P. 2013. Under melting ice, climate change reveals a new archaeology. The Chronicles of Higher Education 60(14). Electronic document, http://go.galegroup.com.libproxy.uwyo.edu/ ps/i.do?id=GALE\%7CA364442266 $\beta=2.1 \mathrm{Bu}$ $=$ wyrc uwyoming $\beta \mathrm{it}=\mathrm{r} \beta \mathrm{p}=\mathrm{AONE} \beta \mathrm{sw}=\mathrm{w} \beta \mathrm{as}$ $\mathrm{id}=976 \mathrm{fd} 658952 \mathrm{efbcbe} 77992 \mathrm{a} 8 \mathrm{cb} 7 \mathrm{f} 721 \mathrm{a}$, accessed May 6, 2015. 